\title{
Erratum to: Hepatopancreatic cells of a stone crab Menippe frontalis from Perú: separation, viability study, and evaluation of lipoperoxidation against cadmium contamination
}

\author{
H. A. Vitorino ${ }^{1}$ - R. Y. P. Alta ${ }^{2}$ - E. C. P. Alta ${ }^{2}$ P. Ortega ${ }^{3}$
}

Published online: 11 July 2017

(C) The Society for In Vitro Biology 2017

ERRATUM TO: In Vitro Cell.Dev.Biol.-Animal

DOI:10.1007/s11626-017-0168-8

The correct names of the second and third authors are R. Y. P. Alta and E. C. P. Alta, respectively.

The original article was corrected.

The online version of the original article can be found under doi:10.1007/ s11626-017-0168-8

P. Ortega

priortega218@gmail.com

1 Center of Natural and Human Sciences, Federal University of ABC, Santo André, Brazil

2 Faculty of Science, National University of Engineering, Lima, Peru

3 Bioscience Institute, University of São Paulo, São Paulo, Brazil 